\title{
design thinking at work
}

how innovative organizations are embracing design 



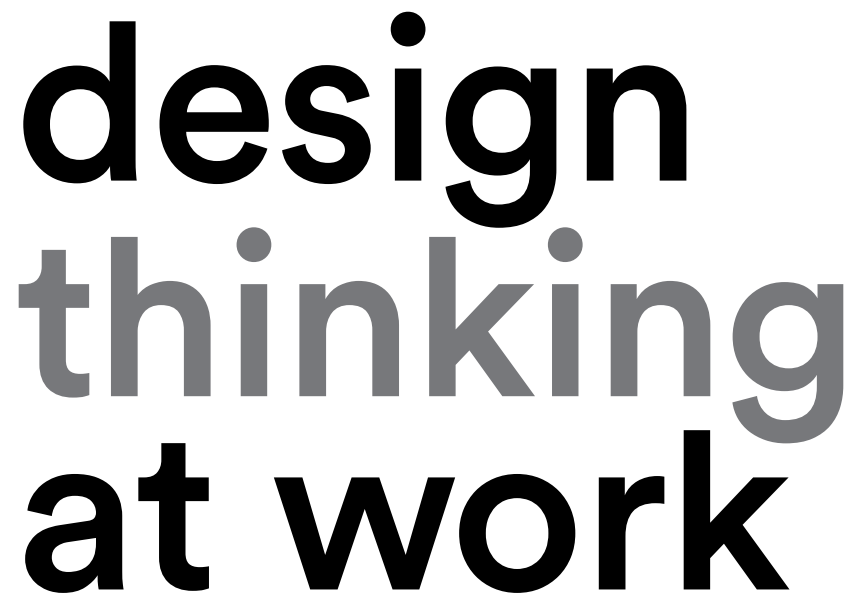

how innovative organizations are embracing design

david dunne

UNIVERSITY OF TORONTO PRESS

Toronto Buffalo London 
(C) University of Toronto Press 2018

Rotman-UTP Publishing

Toronto Buffalo London

utorontopress.com

Printed in Canada

ISBN 978-1-4875-0170-9

( Printed on acid-free, $100 \%$ post-consumer recycled paper with vegetablebased inks.

\section{Library and Archives Canada Cataloguing in Publication}

Dunne, David, 1953-, author

Design thinking at work : how innovative organizations are embracing design / David Dunne.

Includes bibliographical references and index.

ISBN 978-1-4875-0170-9 (hardcover)

1. Organizational change. 2. Design. 3. Creative thinking.

4. Creative ability in business. 5. Problem solving. I. Title.

HD58.8.D86 2018

$658.4^{\prime} 063$

C2018-903608-7

University of Toronto Press acknowledges the financial assistance to its publishing program of the Canada Council for the Arts and the Ontario Arts Council, an agency of the Government of Ontario.

Canada Council Conseil des Arts for the Arts du Canada

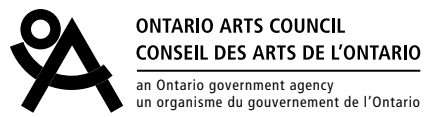


This book is dedicated to my family:

Carol Ann;

Laurence and Liam;

Simon, Leila, and Lee;

and Gavin,

without whose love it would not have been possible. 
This page intentionally left blank 